www.jmscr.igmpublication.org

Impact Factor 3.79

Index Copernicus Value: 5.88

ISSN (e)-2347-176x ISSN (p) 2455-0450

crossref DOI: _http://dx.doi.org/10.18535/jmscr/v4i02.40

Journal Of Medical Science And Clinical Research

IGM Publication

An Official Publication of IGM Publication

\title{
Teacher Training Program for School Eye Screening (Original Article)
}

\author{
Author \\ Dr Shubha Ghonsikar \\ C/o Sachin Hospital, Khadkeshwar, Aurangabad, (Maharashtra) INDIA \\ Email: shubhajhavar@gmail.com
}

\begin{abstract}
Purpose - Teacher training Program implemented for School Eye Screening of Children in Municipal Corporation Schools around Aurangabad with the help of NGO LIONS, with the aim of early detection and treatment of visual defects and eye problemsin school children and the results studied.

Methods- Teachers from 32 Municipal corporation schools around Aurangabad were trained to assess Visual acuity using Standar Vision chart and any Obvious Ocular abnormalities They then examined their class students of age 4-16 yrs and noted their Vision and any eye problem. These were then referred to an ophthalmologist who treated them.

Results-- Examined 9986 students of which 1332 students had Refractive errors and 52 had other eye problems.

Conclusion- Training teachers is a very effective way for early detection and treatment of visual impairment in school children. It is easier, convenient, reliable, cost effective and time saving too.
\end{abstract}

\section{Introduction}

Visual impairment and blindness in Children are very devastating and need immediate address.

Refractive errors especially Myopia in the current world of mobiles, I-Pads, and Computers specially need to be diagnosed early and treated at an early age.

Children are not aware of any refractive error because they adjust to that poor eyesight by squeezing their eyes or sitting close to the T.V. or holding books close eyes. Or start playing, avoiding any closework.

Poor eyesight also plays an important in their Educational standards and Personality development.
Parents often ignore their complaints, delay consulting an Ophthalmologist leading to more cases of amblyopia. Importance of early detection and treatment of Ocular diseases in children can prevent further vision impairment and improve their quality of life.

This article discusses an easy method of training teachers to screen and diagnose vision and eye problems in school going children.

\section{Methods}

We selected 32 municipal corporation schools from District Aurangabad, and trained teachers from these schools to assess Vision of their students and identify obvious ocular problems. This was carried out In September and October 
2015. An NGO Lions Club was involved in helping carry out the program.

On a given date, all the municipal school teachers from around Aurangabad were informed and collected for the training program. 192 teachers gathered and were trained by an Ophthalmologist to assess vision. On another day, Three other Schools were visited by the Ophthalmologist and 38 teachers were also trained.

Teachers Orientation to the importance of their role in diagnosing eye problems at an early age and eye care delivery and counselling parents as well as following up patients for treatment was done.

Teachers were taught to test vision by Standard Vision chart. They were advised about how to apply this chart on the board or wall in the classroom in proper light, at a proper height where child can read easily. From a distance of 20 feet (steps), child is to be asked to read the lines with each eye and the teacher should note what line he reads and thus he notes the vision. They were told about what was- correct (good) vision and what was- incorrect (not good) vision. The teachers then examined each other in front of the ophthalmologist who confirmed their method of examination.

Standard Vision Chart was low cost, non invasive, rapid, reliable and acceptable method. Teachers were explained how children tried to cheat or memorise the chart. So they could also check by a different vernacular language. They were also taught to examine students who were already using spects and check whether their vision with spects was normal or they needed to see the ophthalmologist.

Teachers were also trained to examine the child's eye with torch to examine common eye diseases and note any redness, any white opacity, any abnormally directing eye movement or squint.

Teachers were also asked to counsel students about good and Vitamin rich healthy diet. And the importance of consulting an Ophthalmologist every summer and winter holidays for those who had eye problems.
Teachers were provided with Standard Vision chart, Referral Cards for suspected children and reading material.

The teachers were given 8 days time period to check their students and submit their referral cards.

All children with visual impairment and eye disease were referred to base institution to the Ophthalmologist for Treatment and followup.

\section{Observations}

Total 230 Teachers from 32 Municipal Corporation Schools tending to poor students were trained by a single Ophthalmologist in 2 days.

Total 9986 children were examined out of 10661 students of these schools.

\section{Table 1}

\begin{tabular}{|l|l|l|l|}
\hline $\begin{array}{l}\text { Age } \\
\text { gr(yrs). }\end{array}$ & $\begin{array}{l}\text { Male } \\
(51.56 \%)\end{array}$ & $\begin{array}{l}\text { Female } \\
(48.44 \%)\end{array}$ & Total \\
\hline $4-8$ & $\begin{array}{l}1576 \\
(51.52 \%)\end{array}$ & $\begin{array}{l}1483 \\
(48.48 \%)\end{array}$ & $\begin{array}{l}3059 \\
(30.64 \%)\end{array}$ \\
\hline $8-12$ & $\begin{array}{l}1819 \\
(51.06 \%)\end{array}$ & $\begin{array}{l}1743 \\
(48.94 \%)\end{array}$ & $\begin{array}{l}3562 \\
(35.66 \%)\end{array}$ \\
\hline $12-16$ & $\begin{array}{l}1754 \\
(52.12 \%)\end{array}$ & $\begin{array}{l}1611 \\
(47.88 \%)\end{array}$ & $\begin{array}{l}3365 \\
(33.70 \%)\end{array}$ \\
\hline $4-16$ & 5149 & 4837 & 9986 \\
\hline
\end{tabular}

Table2 Defective Vision

\begin{tabular}{|l|l|l|l|}
\hline $\begin{array}{l}\text { Age gr } \\
\text { yrs }\end{array}$ & $\begin{array}{l}\text { Male } \\
(51.95 \%)\end{array}$ & $\begin{array}{l}\text { Female } \\
(48.05 \%)\end{array}$ & Total \\
\hline $4-8$ & 216 & 200 & 416 \\
\hline $8-12$ & 210 & 190 & 400 \\
\hline $12-16$ & 266 & 250 & 516 \\
\hline $4-16$ & 692 & 640 & 1332 \\
\hline
\end{tabular}

Table 3- Refractive error

\begin{tabular}{|l|l|l|}
\hline Type of Error & No. & $\%$ \\
\hline Myopia & $\begin{array}{l}1100 \\
(82.58 \%)\end{array}$ & $(11 \%)$ \\
\hline Hypermetropia & $232(17.42 \%)$ & $(2.32 \%)$ \\
\hline Total & 1332 & 9986 \\
\hline
\end{tabular}


Table 4 - Eye Problems

\begin{tabular}{|l|l|}
\hline Disease & $\begin{array}{l}\text { No.of } \\
\text { Children }\end{array}$ \\
\hline Allergic Conjunctivitis & 34 \\
\hline Stye & 2 \\
\hline Ptosis & 1 \\
\hline Squint & 8 \\
\hline Corneal Opacity & 3 \\
\hline Congenital disorder. & 4 \\
\hline Total & 52 \\
\hline
\end{tabular}

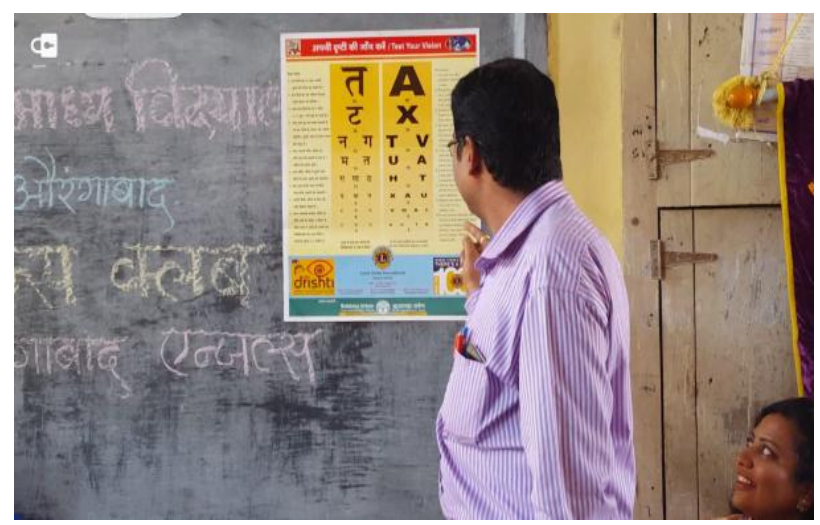

Fig. 1. Teacher training.

\section{Discussion}

Total 9986 students were examined. These students were from Municipal corporation school hence were from poor socioeconomic status. Out of these 1332 students referred to the Ophthalmologist were found to have Refractive Errors. 52 children had other eye problems.

Of these 692 were male students and 640 were female students.

416 students were in the 4-8 yrs age group. 400 students were in the 8-12 age group.

516 students were in the 12-16 age group.

Of the 1332 students 1100 had Myopia and 232 had Hypermetropia.

These children were provided with Spectacles donated by the NGO and were advised about regular follow-up.

52 children were found to have other eye problems. Allergic Conjunctivitis was seen in 34 children, 2 Children had stye, 8 had Squint, 3 had corneal opacities due to old injuries, 1 child had
Ptosis. 4 children had Iris Coloboma. These were all treated for their respective problems.

In world 1.4 million children are blind.Additional 7 million suffer from low vision and further 10 million children have a correctable Refrctive error causing visual impairment.

Prevalence of blindness is estimated to be $0.8 / 1000$ children in age group of $0-15$ yrs. $^{[1]}$

The students in our study were from poor socioeconomic strata, hence more prone for neglect of eye condition. Single Ophthalmologist trained 230 teachers in 2 days. These very well assessed the Vision appropraiately and referred the students to the Ophthalmologist. They had a better raport with the students and their parents, hence easily convinced them.

Nirmalan $\mathrm{Pk}$, identified thinking patterns of parents. ${ }^{\text {[2] }}$

Desai $\mathrm{R}$ studied the ocular morbidity pattern in children and stated that school eye health programs must include teachers. ${ }^{[3]}$

Sudhan A stated that using Teachers to screen school children saved the time of the Ophthalmologist and was quite effective. ${ }^{[4]}$

\section{Conclusion}

Primary Vision screening by Teachers effectively diagnosed refractive errors and other Eye problems like Allergic Conjunctivitis and Squint in poor students .It was Easy, Convenient, Reliable, Cost-effective and Time saving as well.

\section{References}

1. R.Jose,Sandeep Sachdeva. School Eye Screening and the NPCB Ministry of Health and Family welfare Indian Paediatrics 2009March;Vol46:205-8

2. Nirmalan PK,Sheeladevi $S$ et al, Prescriptions of eye diseases and eyecare needs of children among parents in South India. The Kariapatti Paed Eye Evaluation Project (KEEP) Indian J Ophthalmol 2004;52:163-167 
3. Desai S,Desai R et al School Eye Health Appraisal. Indian J Ophthalmol 1989; 37:173-5

4. Sudhan A,Pande A et al Effectiveness of using teachers to screen eyes of school going children in Satna District of MP, India. Indian J Ophthalmol 2009NovDec;57(6):455-8

5. Agrawal S. Screening program of school going children. Indian J Ophthalmol 2010;58:347

6. GVS Murthy Vision testing for Refractive Errors in schools. Community eye health, 2000;13(33):3-5

7. Kalikivayi $\mathrm{V}$ et al Visual impairment in school children in Southern India.Ind J Ophthalmol 1997;45:129-34

8. Limburg $\mathrm{H}$ et al Cost Effective Screening of School Children for Refrective Errors World Health Forum 1995;16:173-8 